\title{
Annual Changes in Forced Expiratory Flows in Toll Collectors: Results from a Four Years Observation
}

\author{
Peri ARBAK ${ }^{1}$, Öner BALBAY ${ }^{1 *}$, Ali Nihat ANNAKKAYA ${ }^{1}$, \\ Cahit BILGIN $^{2}$ and Sefa Levent OZSAHIN ${ }^{3}$
}

\author{
${ }^{1}$ Faculty of Medicine, Department of Chest Diseases, Duzce University, 81620 Konuralp, Duzce, Turkey \\ ${ }^{2}$ Department of Chest Diseases, Hendek Government Hospital, Hendek, Sakarya, Turkey \\ ${ }^{3}$ Faculty of Medicine, Department of Chest Diseases, Cumhuriyet University, Turkey
}

Received June 10, 2008 and accepted November 17, 2008

\begin{abstract}
Diesel exhaust (DE) has been accused for various health outcomes including exacerbation of asthma, chronic bronchitis. Exposure to DE has long-term effects on lung development in children and reductions in lung function have been reported. The aim of the study was to evaluate the annual changes in forced expiratory flows among toll collectors in Duzce city from 2002 to 2005. Annual FVC, FEV 1 and MMF changes in smoker and nonsmoker 58 toll collectors and 37 controls selected among men who worked in the same company as officer have been followed up. No significant changes were seen in expiratory flows among smoker-nonsmoker toll collectors and controls $(p>0.05)$. Annual FVC, FEV 1 and MMF changes were not significantly different between smoker and nonsmoker toll collectors. Twelve toll collectors $(20.7 \%)$ in the study group and $4(\mathbf{1 0 . 8 \%})$ controls were found to have $\mathrm{FEV}_{1}$ and FVC below longitudinal lower limit of normal. The difference between groups did not reach statistically significance $(p>0.05)$. Toll collectors (18/58) and controls (15/37) with spirometric measurements for three times showed no difference according to the rate of annual difference in either $\mathrm{FEV}_{1}(-21.3 \pm 133.1 \mathrm{ml} / \mathrm{yr} \mathrm{vs}$ $-44.3 \pm 166.6(\mathrm{ml} / \mathrm{yr})$ or FVC $(13.2 \pm 202.9 \mathrm{ml} / \mathrm{yr}$ vs. $-16.1 \pm 204.2 \mathrm{ml} / \mathrm{yr})$. Further investigations including large groups with long term follow up are needed to observe annual FVC, $\mathrm{FEV}_{1}$ and MMF changes among toll collectors.
\end{abstract}

Key words: Annual changes, Forced expiratory flows, Toll collectors

\section{Introduction}

It has been suggested that both acute exposure to high levels of diesel exhaust (DE) particles and chronic exposure to low levels may impair respiratory functions and have various other detrimental effects ${ }^{1)}$. The acute effects have primarily been due to the inflammation (upper and lower airways) and resulted in lung function changes especially in asthmatics and in subjects with concomitant obstructive pulmonary diseases ${ }^{2,3}$. As shown in animal studies with chronic exposure, increased numbers of particles in the lung, alveolar macrophage reflux, chronic inflammatory responses, thickening of alveolar septa are

*To whom correspondence should be addressed caused by both the gaseous components and particulate content of DE. The hazards of particulate matter include oxidative stress and effects related to metals, hydrocarbon, acids, carbon core and ultrafine particles ${ }^{1}$.

Some previous studies have shown an association between chronic exposure to automobile exhaust and adverse effects on respiratory symptoms and pulmonary function in humans ${ }^{4-6)}$. A few studies focused on manual tollbooth collectors reported acute irritative symptoms due to nasal and throat inflammation, nausea, headache and lower peak expiratory flow rates ${ }^{7,8}$.

The aim of this longitudinal study was to evaluate the long term effects of DE on pulmonary function of a highly specific occupational group named as toll collectors. 


\section{Subjects and Methods}

A total of 58 highway toll collectors (HTC) working 8 $\mathrm{h}$ a day in tollbooths in Kaynasli and Golyaka towns in Duzce, a city in the northwest part of Turkey, constituted the study group. Between September 2002 and September 2005, subjects were invited to perform annual pulmonary function tests. The data of subjects with at least two sets of lung function measurements were used in analysis. Thirty seven office workers in same company served as controls. All of the study group and controls were men. All workers participated in the health check-up, which was carried out primarily at the hospital of Duzce University. A respiratory questionnaire regarding respiratory complaints (dyspnea, cough, sputum and chest tightness), previous pulmonary diseases, family history for respiratory diseases and smoking status was completed by all subjects9). An informed consent was obtained from all subjects and the study was approved by Duzce University Faculty of Medicine Ethics Committee. Questionnaires were administered by the same physician who also performed the physical examination and spirometric measurements. Spirometric measurements were performed using the same spirometer (Vitalograph Alpha). All annual measurements were done in spring. Calibrations and the measurements were performed in accordance with the guidelines recommended by the American Thoracic Society (ATS) ${ }^{10)}$. According to the ATS criteria, individual spirograms were acceptable if exhalation time was satisfactory (e.g. $6 \mathrm{sec}$ ). Measurements fulfilled the reproducibility criteria if two largest $\mathrm{FEV}_{1}$ and FVC were within $200 \mathrm{ml}$ of each other among three acceptable spirograms. Recorded variables were forced vital capacity (FVC) and forced expiratory volume in one second $\left(\mathrm{FEV}_{1}\right)$ and maximal expiratory flow at $25-75 \%$ of FVC (MMF). The lung function variables were expressed in absolute values and as percentages of the predicted values. The change in lung function $(\triangle \mathrm{FVC}$ and $\triangle \mathrm{FEV}_{1}$ ) was defined as the difference between lung function at the last observation and the first observation. Negative values indicate a decrease in lung function.

With an additional calculation annual changes in $\mathrm{FEV}_{1}$ and FVC were evaluated with two methods suggested by American College of Occupational and Environmental Medicine (ACOEM).

Method 1 for BASELINES $>100 \%$ Predicted: Evaluate Change in \% Predicted

Longitudinal Lower Limit of Normal (LLN) for Followup $\mathrm{FEV}_{1}$ (or FVC) \% Predicted $=[0.85 \times$ Baseline $\%$ Predicted].

Method 2 for BASELINES $\leq 100 \%$ Predicted: Evaluate Change in Measured Values

Longitudinal LLN for Follow-up Measured $\mathrm{FEV}_{1}$ (or
FVC $)=[0.85 \times$ Baseline Measured Value $-($ Baseline Predicted - Follow-up Predicted)].

Each serial test can be compared to the LLN to determine whether the worker's pulmonary function has deteriorated significantly regarding to his/her measured baseline value.

A third formula was used to evaluate the first and the last year of the follow-up changes in few cases (toll collector \#7 and controls \#3 and \#4).

LLN $=0.85^{*}$ baseline $-\left(\mathrm{N}_{\text {years of follow-up }} * 0.025\right)^{11)}$.

\section{Statistics}

SPSS version 11.0 for Windows was used for data description and analysis. The $\chi^{2}$ test was used for testing differences in the prevalence of respiratory symptoms among the groups. Comparison of spirometric measurements was performed by $t$-test for two independent samples. Association between variables was analyzed with $\chi^{2}$ (or when appropriate Fisher's exact test) and MannWhitney U-test. The change in lung function $(\triangle \mathrm{FVC}$ and $\triangle \mathrm{FEV}_{1}$ ) was defined as the difference between lung function at the last observation and the first observation (negative values indicate a decrease in lung function). Individual lung function changes were evaluated by comparing the lung function at first and last observation using paired $t$ tests.

A $p$-value less than 0.05 was considered as statistically significant.

\section{Results}

Mean age was $34.1 \pm 6.5 \mathrm{yr}$ in toll collectors and $34.4 \pm 7.4 \mathrm{yr}$ in controls. Mean working duration of toll collectors and controls were $12.9 \pm 4.3$ and $14.5 \pm 8.2 \mathrm{yr}$, respectively. Thirty six toll collectors $(62.1 \%)$ and 25 controls (67.6\%) were active smokers and no significant difference was observed between groups according to the smoking status. Three toll collectors have had history of asthma, pulmonary tuberculosis and pleurisy, respectively. Four controls reported history of asthma, pulmonary tuberculosis (2 subjects) and cardiac valvular replacement, respectively.

Higher rates of sputum (41.4\%) and dyspnea (10.3\%) were reported by toll collectors, but there were no significant differences between groups related with respiratory complaints $(p>0.05)$. The aspects of respiratory symptoms in subjects are seen in Table 1 . No differences were observed between toll collectors and controls related to the presence of cough or sputum at least 3 months a year, duration of cough or sputum, presence of winter cough, presence of wheezing under age of $16 \mathrm{yr}$.

The changes in FVC, $\mathrm{FEV}_{1}$ and MMF values within the study period are shown in Table 2. No significant dif- 
Table 1. The aspects of respiratory symptoms in toll collectors and controls

\begin{tabular}{|c|c|c|c|c|c|}
\hline & \multicolumn{2}{|c|}{$\begin{array}{c}\text { TOLL } \\
\text { COLLECTORS }\end{array}$} & \multicolumn{2}{|c|}{ CONTROLS } & \multirow[t]{2}{*}{$p$} \\
\hline & $\mathrm{N}=58$ & $(\%)$ & $\mathrm{N}=37$ & $(\%)$ & \\
\hline Cough & 10 & 17.2 & 10 & 27.0 & NS \\
\hline Morning cough & 10 & 17.2 & 10 & 27.0 & NS \\
\hline At least three months a year & 5 & 8.6 & 4 & 10.8 & NS \\
\hline Less than $2 \mathrm{yr}$ & 5 & 8.6 & 4 & 10.8 & NS \\
\hline More than $2 \mathrm{yr}$ & 5 & 8.6 & 6 & 16.2 & NS \\
\hline Sputum & 24 & 41.4 & 12 & 32.4 & NS \\
\hline Morning sputum & 24 & 41.4 & 12 & 32.4 & NS \\
\hline At least three months a year & 12 & 20.7 & 7 & 18.9 & NS \\
\hline Less than $2 \mathrm{yr}$ & 7 & 12.1 & 4 & 10.8 & NS \\
\hline More than $2 \mathrm{yr}$ & 17 & 29.3 & 8 & 21.6 & NS \\
\hline Wheezing & 14 & 24.1 & 13 & 35.1 & NS \\
\hline Wheezing under the age of $16 \mathrm{yr}$ & - & - & 1 & 2.7 & NS \\
\hline Chest tightness & 11 & 19.0 & 12 & 32.4 & NS \\
\hline Dyspnea & 6 & 10.3 & 2 & 5.4 & NS \\
\hline
\end{tabular}

The Fisher's exact test was used to test the differences between rates for statistical significance.

Table 2. Expiratory flows of toll collectors and controls

\begin{tabular}{|c|c|c|c|c|c|c|c|c|}
\hline & $\mathrm{FEV}_{1}$ & \multirow[t]{2}{*}{$p$} & $\mathrm{FVC}$ & \multirow[t]{2}{*}{$p$} & \multicolumn{2}{|c|}{ MMF } & \multirow[t]{2}{*}{$p$} \\
\hline & & MEAN & & MEAN & & MEAN & SD & \\
\hline \multicolumn{9}{|l|}{2002} \\
\hline Toll coll & $\mathrm{n}=41$ & $4221.7 \pm 644.8$ & \multirow[t]{2}{*}{ NS } & $4986.1 \pm 755.0$ & \multirow[t]{2}{*}{ NS } & $4764.6 \pm$ & 311.0 & \multirow[t]{2}{*}{ NS } \\
\hline Controls & $\mathrm{n}=17$ & $4284.7 \pm 574.5$ & & $5094.1 \pm 659.3$ & & $4479.1 \pm$ & 86.6 & \\
\hline \multicolumn{9}{|l|}{2003} \\
\hline Toll coll & $\mathrm{n}=44$ & \multirow{2}{*}{$\begin{array}{l}4106.3 \pm 753.3 \\
4215.2 \pm 630.1\end{array}$} & NS & \multirow{2}{*}{$\begin{array}{l}4816.8 \pm 880.6 \\
4816.6 \pm 595.4\end{array}$} & NS & \multirow{2}{*}{\multicolumn{2}{|c|}{$\begin{array}{l}4468.1 \pm 1231.1 \\
4754.7 \pm 1138.4\end{array}$}} & NS \\
\hline Controls & $\mathrm{n}=36$ & & & & & & & \\
\hline \multicolumn{9}{|l|}{2004} \\
\hline Toll coll & $\mathrm{n}=31$ & \multirow{2}{*}{$\begin{array}{l}3917.4 \pm 804.0 \\
4122.9 \pm 758.5\end{array}$} & NS & \multirow{2}{*}{$\begin{array}{l}4751.3 \pm 1115.5 \\
5043.3 \pm 877.8\end{array}$} & NS & \multirow{2}{*}{\multicolumn{2}{|c|}{$\begin{array}{l}3950.3 \pm 1195.1 \\
3987.5 \pm 1270.1\end{array}$}} & NS \\
\hline Controls & $\mathrm{n}=24$ & & & & & & & \\
\hline \multicolumn{9}{|c|}{2005} \\
\hline Toll coll & $\mathrm{n}=29$ & \multirow{2}{*}{$\begin{array}{l}4031.7 \pm 650.4 \\
3938.3 \pm 611.9\end{array}$} & NS & \multirow{2}{*}{$\begin{array}{l}4995.1 \pm 925.0 \\
4685.0 \pm 604.2\end{array}$} & NS & \multirow{2}{*}{\multicolumn{2}{|c|}{$\begin{array}{l}3956.5 \pm 1122.9 \\
4179.4 \pm 1313.3\end{array}$}} & NS \\
\hline Controls & $\mathrm{n}=18$ & & & & & & & \\
\hline
\end{tabular}

Note: Mean FEV1 and FVC expressed as $\mathrm{ml}$, and MMF expreseed as $\mathrm{ml} / \mathrm{s}$,

The Mann Whitney U test was used to test the differences between expiratory flows for statistical significance.

ferences were observed between groups according to the absolute values of expiratory flow rates within follow-up time $(p>0.05)$. Comparisons of annual changes in FVC, $\mathrm{FEV}_{1}$ and MMF during years of 2002-2005 are presented in Fig. 1. There were no significant differences in annual changes in FVC, $\mathrm{FEV}_{1}$ and MMF among toll collectors. A significant change in MMF 2003-2004 among controls was observed $(p=0.008)$. No significant changes were seen in expiratory flows among smoker-nonsmoker toll collectors and controls $(p>0.05)$.

The data of toll collectors and controls whose followup lung function values were below LLN are shown in
Table 3 and 4, respectively. Twelve subjects $(20.7 \%)$ in the group of toll collectors and four $(10.8 \%)$ in the control group were found to have $\mathrm{FEV}_{1}$ or FVC below LLN. The difference between the two groups did not reach statistical significance $(p>0.05)$. Both $\mathrm{FEV}_{1}$ and FVC were found simultaneously to be below LLN in four toll collectors, but in no subject of the control group. Four toll collectors showed only $\mathrm{FEV}_{1}$ below LLN and four other toll collectors only FVC below LLN during the followup period. In the control group, two subjects had only FEV $_{1}$ below LLN and two other subjects only FVC below LLN. 


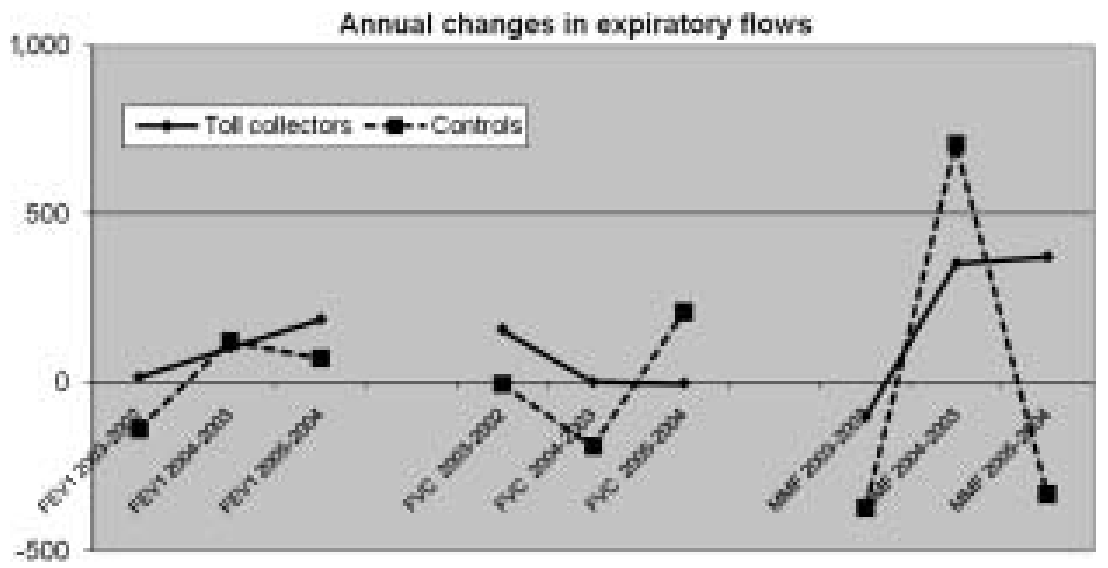

Fig. 1. Annual changes in expiratory flows.

Note: Mean $\mathrm{FEV}_{1}$ and $\mathrm{FVC}$ expressed as $\mathrm{ml}$, and MMF expressed as $\mathrm{ml} / \mathrm{s}$.

Table 3. Toll collectors whose follow-up values were below LLN

\begin{tabular}{|c|c|c|c|c|c|c|c|c|}
\hline & AGE & $\begin{array}{l}\mathrm{FEV}_{1} \\
\text { (L) }\end{array}$ & $\begin{array}{l}\mathrm{FEV}_{1} \\
\text { (\%predicted) }\end{array}$ & LLN & $\begin{array}{l}\text { FVC } \\
\text { (L) }\end{array}$ & $\begin{array}{l}\text { FVC } \\
\text { (\%predicted) }\end{array}$ & LLN & \\
\hline Toll & 37 & 4.70 & 126 & $107 \quad(\%)$ & 4.84 & 108 & 92 & $(\%)$ \\
\hline Collector 1 & 38 & 3.61 & 99 & $3.96(\mathrm{~L})$ & 4.43 & 102 & 87 & $(\%)$ \\
\hline Toll & 42 & 4.00 & 118 & $100(\%)$ & 5.02 & 123 & 104 & $(\%)$ \\
\hline \multirow[t]{2}{*}{ Collector 2} & 44 & 3.72 & 113 & $96(\%)$ & 4.81 & 112 & 95 & $(\%)$ \\
\hline & 45 & 3.11 & 94 & $3.37(\mathrm{~L})$ & 4.95 & 124 & 105 & $(\%)$ \\
\hline Toll & 35 & 3.88 & 103 & $88 \quad(\%)$ & 4.01 & 89 & 3.03 & (L) \\
\hline \multirow[t]{2}{*}{ Collector 3} & 36 & 3.14 & 87 & $2.65(\mathrm{~L})$ & 3.63 & 81 & 3.07 & (L) \\
\hline & 38 & 3.20 & 88 & $2.71(\mathrm{~L})$ & 3.62 & 82 & 3.07 & (L) \\
\hline Toll & 39 & 4.36 & 119 & $101(\%)$ & 5.19 & 119 & 101 & $(\%)$ \\
\hline \multirow[t]{3}{*}{ Collector 4} & 40 & 5.26 & 144 & $122(\%)$ & 5.85 & 133 & 113 & $(\%)$ \\
\hline & 41 & 4.13 & 113 & $96(\%)$ & 4.52 & 102 & 86 & $(\%)$ \\
\hline & 42 & 3.53 & 98 & $2.98(\mathrm{~L})$ & 4.32 & 99 & 3.66 & (L) \\
\hline Toll & 29 & 4.91 & 109 & $92(\%)$ & 6.50 & 123 & 104 & $(\%)$ \\
\hline \multirow[t]{3}{*}{ Collector 5} & 30 & 3.85 & 90 & $3.25(\mathrm{~L})$ & 5.55 & 105 & 89 & $(\%)$ \\
\hline & 31 & 4.55 & 105 & $89(\%)$ & 6.50 & 125 & 106 & $(\%)$ \\
\hline & 32 & 4.23 & 99 & 3.59 (L) & 6.40 & 124 & 105 & (\%) \\
\hline Toll & 32 & 4.72 & 109 & $92(\%)$ & 5.59 & 108 & 92 & $(\%)$ \\
\hline \multirow[t]{2}{*}{ Collector 6} & 33 & 4.22 & 93 & $3.60(\mathrm{~L})$ & 4.53 & 83 & 3.82 & \\
\hline & 35 & 4.89 & 110 & $93(\%)$ & 5.71 & 106 & 90 & $(\%)$ \\
\hline Toll & 43 & 4.22 & 118 & $100(\%)$ & 4.69 & 108 & 92 & $(\%)$ \\
\hline \multirow[t]{2}{*}{ Collector 7} & 45 & 3.94 & 108 & $92(\%)$ & 4.07 & 92 & 3.44 & (L) \\
\hline & 46 & 3.43 & 95 & $2.90(\mathrm{~L})$ & 3.86 & 87 & 3.27 & (L) \\
\hline Toll & 35 & 4.54 & 112 & $95(\%)$ & 5.08 & 105 & 89 & $(\%)$ \\
\hline Collector 8 & 36 & 3.89 & 97 & $3.29(\mathrm{~L})$ & 4.12 & 85 & 3.48 & (L) \\
\hline Toll & 38 & 4.41 & 119 & $101(\%)$ & 5.28 & 118 & 100 & $(\%)$ \\
\hline Collector 9 & 39 & 3.68 & 99 & $3.11(\mathrm{~L})$ & 4.24 & 95 & 3.58 & (L) \\
\hline Toll & 35 & 4.75 & 112 & $95(\%)$ & 6.07 & 119 & 101 & $(\%)$ \\
\hline \multirow[t]{2}{*}{ Collector 10} & 36 & 3.92 & 93 & $3.31(\mathrm{~L})$ & 4.69 & 92 & 4.02 & (L) \\
\hline & 37 & 4.86 & 116 & $98 \quad(\%)$ & 6.75 & 133 & 113 & $(\%)$ \\
\hline Toll & 25 & 4.65 & 114 & $97(\%)$ & 5.48 & 92 & 4.73 & (L) \\
\hline Collector 11 & 26 & 4.08 & 106 & $90 \quad(\%)$ & 4.72 & 86 & 4.00 & (L) \\
\hline Toll & 43 & 4.11 & 107 & $91 \quad(\%)$ & 4.82 & 103 & 87 & $(\%)$ \\
\hline Collector 12 & 44 & 3.61 & 94 & $3.05(\mathrm{~L})$ & 3.71 & 79 & 3.13 & (L) \\
\hline
\end{tabular}

Note: Numeric values with bold character refer to the results below LLN of FEV1 and FVC during follow-up period. 
Table 4. Controls whose follow-up values were below LLN

\begin{tabular}{llllllll}
\hline & AGE & $\begin{array}{l}\text { FEV }_{1} \\
(\mathrm{~L})\end{array}$ & $\begin{array}{l}\mathrm{FEV}_{1} \\
(\% \text { predicted })\end{array}$ & LLN & $\begin{array}{l}\text { FVC } \\
(\mathrm{L})\end{array}$ & $\begin{array}{l}\text { FVC } \\
(\% \text { predicted })\end{array}$ & LLN \\
\hline Control 1 & 33 & 3.32 & 86 & $2.38(\mathrm{~L})$ & 4.64 & 102 & $87(\%)$ \\
& 34 & 3.35 & 89 & $2.85(\mathrm{~L})$ & 4.66 & 103 & $88(\%)$ \\
& $\mathbf{3 5}$ & 2.88 & 74 & $2.43(\mathrm{~L})$ & 3.88 & $\mathbf{8 5}$ & $2.04(\mathrm{~L})$ \\
Control 2 & 34 & 4.25 & 102 & $87(\%)$ & 5.23 & 104 & $88(\%)$ \\
& 35 & 3.56 & $\mathbf{8 6}$ & $3.01(\mathrm{~L})$ & 4.56 & 91 & $3.86(\mathrm{~L})$ \\
& 36 & 3.83 & 96 & $3.26(\mathrm{~L})$ & 4.55 & 95 & $3.87(\mathrm{~L})$ \\
Control 3 & 36 & 4.60 & 123 & $105(\%)$ & 5.39 & 123 & $104(\%)$ \\
& 37 & 4.87 & 133 & $113(\%)$ & 5.23 & 117 & $99(\%)$ \\
& 38 & 4.03 & 110 & $93(\%)$ & 4.55 & $\mathbf{1 0 3}$ & $87(\%)$ \\
Control 4 & 39 & 4.06 & 113 & $96(\%)$ & 4.63 & 107 & $91(\%)$ \\
& 34 & 5.13 & 120 & $102(\%)$ & 5.77 & 112 & $95(\%)$ \\
& 35 & 4.80 & 110 & $93(\%)$ & 5.43 & 103 & $87(\%)$ \\
& 36 & 4.75 & 112 & $95(\%)$ & 5.56 & 109 & $93(\%)$ \\
& 37 & 4.11 & $\mathbf{1 0 1}$ & $85(\%)$ & 4.71 & 96 & $3.98(\mathrm{~L})$ \\
\hline
\end{tabular}

Table 5. A comparative presentation of mean annual changes in flows in subjects with spirometric measurements for 2,3 and 4 times

\begin{tabular}{lcrrrr}
\hline \multirow{2}{*}{ Number of spirometric measurements } & \multicolumn{2}{c}{ Toll collectors } & \multicolumn{2}{c}{$\begin{array}{c}\text { Controls } \\
\mathrm{n}=37\end{array}$} & $p$ \\
& \multicolumn{1}{c}{$\Delta \mathrm{FEV}_{1}$} & \multicolumn{1}{c}{$\Delta \mathrm{FVC}$} & \multicolumn{1}{c}{$\Delta \mathrm{FEV}_{1}$} & \multicolumn{1}{c}{$\Delta \mathrm{FVC}$} \\
\hline 2 times (58 toll collectors, 37 controls) & $-71.8 \pm 422.1$ & $-55.4 \pm 657.6$ & $8.1 \pm 259.8$ & $79.8 \pm 359.1$ & $\mathrm{NS}$ \\
3 times (18 toll collectors, 15 controls) & $-21.3 \pm 133.1$ & $13.2 \pm 202.9$ & $-44.3 \pm 166.6$ & $-16.1 \pm 204.2$ & $\mathrm{NS}$ \\
4 times (5 toll collectors, 3 controls) & $-56.5 \pm 129.7$ & $-75.4 \pm 109.6$ & $-145.0 \pm 105.3$ & $-8.7 \pm 256.3$ & $\mathrm{NS}$ \\
\hline
\end{tabular}

Note: Mean $\mathrm{FEV}_{1}$ and $\mathrm{FVC}$ expressed as $\mathrm{ml}$, $\Delta$ refers to mean annual changes.

The Mann Whitney $\mathrm{U}$ test was used to test the differences between mean annual changes (in $\mathrm{FEV}_{1}$ and FVC) for statistical significance.

Number of spirometric measurements that were performed for each same subject was shown in Table 5. No significant differences were observed between groups according to the data obtained from same subjects underwent spirometric measurements for 2, 3 or 4 times.

\section{Discussion}

The results of the current study suggest that the follow up of $\mathrm{FEV}_{1}$ and FVC values for four years did not show an accelerated decline in toll collectors compared to office workers, who served as controls, in the same company. However, the number of toll collectors who had at least $\mathrm{FEV}_{1}$ or FVC below LLN (12/58) was more than that of office workers (4/37).

In a longitudinal study including 5,682 female adults living in the Tokyo metropolitan area were followed up for $8 \mathrm{yr}$. The subjects were divided into three groups by the level of air pollution they were exposed to during the study period. The concentrations of nitrogen dioxide and suspended particulate matter were the highest in group 1, and the lowest in group 3. The subjects living in areas with high levels of air pollution showed higher prevalence rates of respiratory symptoms (especially phlegm and breathlessness) and a larger decrease of $\mathrm{FEV}_{1}(-0.020$ 1/y vs. $-0.009 \mathrm{l} / \mathrm{y}$ ) compared with those living in areas with low levels of air pollution. The authors concluded that since the traffic density is larger in areas with high air pollution, the differences among the groups may reflect the effect of air pollution attributable to particulate matter found in automobile exhaust ${ }^{12)}$. The major drawbacks of our study were the limited sample size and shorter duration of observation. However, sputum and dyspnea were the most recorded complaints by toll collectors similar to females living in Tokyo metropolitan. Toll collectors and controls with spirometric measurements for three times showed no difference according to the rate of annual difference in either $\mathrm{FEV}_{1}(-21.3 \pm 133.1 \mathrm{ml} / \mathrm{yr}$ vs $-44.3 \pm 166.6(\mathrm{ml} / \mathrm{yr})$ or FVC $(13.2 \pm 202.9 \mathrm{ml} / \mathrm{yr}$ vs. $-16.1 \pm 204.2 \mathrm{ml} / \mathrm{yr}$ ). On the other hand, the number of toll collectors who had $\mathrm{FEV}_{1}$ and FVC values below LLN during the observation period was more than those of controls. An important point to keep in mind was that high SD were related to abnormal distribution and extreme values of mean annual changes in flows in subjects with spirometric measurements for 2,3 and 4 times. If we could observe toll collectors for longer periods, the decrease in annual expiratory flows might be detected. 
Furthermore, an improved method proposed by Hnizdo et al., defining the reference limit of longitudinal annual FEV $_{1}$ decline (LLD) based on the precision of the spirometric data, should be introduced in future studies ${ }^{13)}$.

DeToni et al., in a study including 290 traffic policemen, reported no difference in the 5 yr follow-up data of $\mathrm{FEV}_{1}$ and $\mathrm{FVC}$ between traffic policemen and administrative workers. Authors found that upper respiratory symptoms were higher in traffic policemen ${ }^{14)}$. The results of that study were found to be similar to those of the present study. The present study shows that no significant differences were observed between toll collectors and office workers according to the absolute values of expiratory flow rates within the follow-up time. There were no significant differences in annual changes in FVC, $\mathrm{FEV}_{1}$ and MMF among toll collectors. Additionally no significant annual changes were seen in expiratory flows among smoker-nonsmoker toll collectors and controls in the present study. Working conditions of traffic policemen such as working primarily outdoor can be a reasonable explanation for unchanged follow-up expiratory flows in the study by DeToni et al. One could be expected that exposure to exhaust indoor (garages, non-ventilated tollbooths) might be hazardous at shorter durations. Although no significant differences were observed according to the annual changes in $\mathrm{FEV}_{1}$ and $\mathrm{FVC}$ among toll collectors, toll collectors with decrease in $\mathrm{FEV}_{1}$ and $\mathrm{FVC}$ below LLN were more than controls. Karacan et al., in a study including 251 traffic policemen, have found that annual mean $\mathrm{FEV}_{1}$ loss was $26 \mathrm{ml}$ for traffic policemen $(28 \mathrm{ml}$ and $24 \mathrm{ml}$ for smokers and non smokers, respectively) and $7 \mathrm{ml}$ for control group during two year follow-up period ${ }^{15}$. Difference between the studies by DeToni and Karacan might be related to different air pollution degrees, laws about preventive measures against air pollution in two countries (Italy and Turkey).

The present study has some limitations including small sample size (due to the transformation of tollbooths to an automated system) and relatively shorter observation periods. On the other hand, some outcomes of the present study such as the detection of higher rates of decreased $\mathrm{FEV}_{1}$ and FVC below LLN, and presence of sputum and dyspnea in toll collectors would provide a remarkable impetus in terms of conducting new studies in this area.

\section{References}

1) Sydbom A, Blomberg A, Parnia S, Stenfors N, Sandström T, Dahlen SE (2001) Health effects of diesel exhaust emissions. Eur Respir J 17, 733-46.

2) Diaz-Sanchez D (1997) The role of diesel exhaust particles and their associated polyaromatic hydrocarbons in the induction of allergic airway disease. Allergy $\mathbf{5 2}$, 52-6.

3) U.S. Environment Protection Agency, National Center for Environmental Assessment (2002) Health Assessment Document for Diesel Engine Exhaust. EPA 600/890/057F, Washington DC.

4) Evans RG, Webb K, Homan S, Ayres SM (1988) Crosssectional and longitudinal changes in pulmonary function associated with automobile pollution among bridge and tunnel officers. Am J Ind Med 14, 25-36.

5) Gamble J, Jones W, Minshall S (1987) Epidemiologicalenvironmental study of diesel bus garage workers: chronic effects of diesel exhaust on the respiratory system. Environ Res 44, 6-17.

6) Raaschou-Nielsen O, Nielsen ML, Gehl J (1995) Traffic-related air pollution: exposure and health effects in Copenhagen street cleaners and cemetery workers. Arch Environ Health 50, 207-13.

7) Yang CY, Chen YF, Chuang HY, Cheng BH, Sung FC, Wu TN (2002) Respiratory and irritant health effects in tollbooth collectors in Taiwan. J Toxicol Environ Health A 65, 237-43.

8) Arbak P, Yavuz O, Bukan N, Balbay O, Ulger F, Annakkaya AN (2004) Serum Oxidant and Antioxidant Levels in Diesel Exposed Toll Collectors. J Occup Health 46, 281-8.

9) Minette A (1989) Questionnaire of the European Community for Coal and Steel (ECSC) on respiratory symptoms. 1987 —updating of the 1962 and 1967 questionnaires for studying chronic bronchitis and emphysema. Eur Respir J 2, 165-77.

10) American Thoracic Society (1995) Standardization of spirometry-1994 update. Am J Rcspir Crit Care Med 152, 1107-36.

11) Townsend MC (2000) ACOEM position statement. Spirometry in the occupational setting. American College of Occupational and Environmental Medicine. J Occup Environ Med 42, 228-45.

12) Sekine K, Shima M, Nitta Y, Adachi M (2004) Long term effects of exposure to automobile exhaust on the pulmonary function of female adults in Tokyo, Japan. Occup Environ Med 61, 350-7.

13) Hnizdo E, Sircar K, Yan T, Harber P, Fleming J, Glindmeyer HW (2007) Limits of longitudinal decline for the interpretation of annual changes in $\mathrm{FEV}_{1}$ in individuals. Occup Environ Med 64, 701-7.

14) DeToni A, Larese Filon F, Finotto L (2005) Respiratory diseases in a group of traffic police officers: results of a 5-year follow-up. G Ital Med Lav Ergon 27, 380-2 (in Italian).

15) Karacan O, Arbak P, Ozsahin SL, Ulger F, Numanoglu $\mathrm{N}$ (2001) Evaluation of occupational exposure in traffic policemen by pulmonary function tests, Signs and symptoms related with pulmonary system. Solunum 3, 276-81 (in Turkish). 